\title{
ENVIRONMENTAL RADIOLOGY AND QUALITY ASSURANCE FOR NPP SITE SELECTION
}

\author{
Susetyo Trijoko ${ }^{*}$, Fepriadi $^{1}$ \\ 1) Pusat Kajian Sistem Energi Nuklir (PKSEN) - Badan Tenaga Nuklir Nasional \\ (BATAN), Jalan KH Abdul Rohim, Mampang Prapatan, Jakarta, Indonesia 12710 \\ *Corresponding author: strijoko@batan.go.id
}

\begin{abstract}
ABSTRAK
RADIOLOGI LINGKUNGAN DAN JAMINAN MUTU UNTUK PEMILIHAN TAPAK PLTN. Tulisan ini dimaksudkan untuk menjelaskan secara ringkas tentang radiologi lingkungan dan jaminan mutu dalam rangka pemilihan tapak PLTN, yang disusun bersadarkan peraturan, dokumen standar dan literatur nasional dan internasional. Pemilihan tapak yang berada di tepi pantai perlu dilakukan melalui penelitian dengan memperhatikan kondisi meteorologi setempat, sebaran lepasan radioaktif melalui udara dan badanair, dan batasan dosis radiasi yang akan diterima penduduk. Pengukuran dan pemantauan radiologi lingkungan harus diprogramkan dan dilaksanakan mulai dari tahap awal pemilihan tapak sampai dengan penyelesaian dekomisioning. Program jaminan mutu pengukuran sampel dan radiologi lingkungan harus ditetapkan untuk menjamin keabsahan hasil pengukuran dan harus ditinjau serta diverifikasi oleh pihak independen yang tidak terlibat secara langsung dalam pengukuran dan penelitian.
\end{abstract}

Kata kunci : jaminan mutu, PLTN, radiologi lingkungan

\begin{abstract}
ENVIRONMENTAL RADIOLOGY AND QUALITY ASSURANCE FOR NPP SITE SELECTION. This research briefly explains environmental radiology and quality assurance for NPP sites compiled from regulations, standard documents, and national and international literature. The selection of sites on the coast needs to be performed through research concerning local meteorological conditions with radioactive elements distributed to humans and the surrounding environment through the air and water body. Environmental radiology measurements and monitoring need to be programmed and implemented starting from the initial stage of site selection to the decommissioning. Quality assurance programs for sample measurements and environmental radiology have to be established to ensure the validity of measurement results and have to be reviewed and verified by independents which indirectly involved in measurement and research.
\end{abstract}

Keywords: environmental radiology, quality assurance, NPP

\section{INTRODUCTION}

A nuclear power plant (NPP) is a reactor that uses heat energy from nuclear fission for power generation. A NPP site is an area used for the construction, operation, and decommissioning of one or more nuclear installations and other related systems [1]. Its construction starts from the site selection until the completion stage. However, the construction of the plant is related to environmental radiation. In order to monitoring the environmental radiation, the Indonesian Nuclear Energy Regulatory Agency (BAPETEN) applies regulations to analyze the characteristics of site plants and its peripheral [2]. Conversely, National Nuclear Energy Agency (BATAN) issued radiation protection and safety guidelines that contain procedures for monitoring radiation exposure and radioactive contamination inside and outside the facility [3].

Furthermore, a quality assurance program is required to perform radiological 
measurements and environmental monitoring during site selection, construction, operation, and decommissioning. It is also needed to ensure the adequacy and validity of the measurement results and identify possible weaknesses in the sampling and measurement process. The results from a review of national and international literature and intended to describe environmental radiology and quality assurance in selecting a NPP site to comply with regulations and standards.

\section{NPP SITE ENVIRONMENTAL RADIOLOGY}

The various areas for prospective NPP sites need to be identified in accordance with natural conditions and human activities. The site selection process is carried out with presurvey, survey, and evaluation stages in accordance with the IAEA's recommendations [4]. The pre-survey activity is intended to obtain areas of interest with fairly broad coverage. Furthermore, the International Atomic Energy Agency also recommended limiting site survey activities by specifying the research radius's scope and stages [4].

The regional scale coverage radius, near and tread areas, and surrounding site are approximately $150 \mathrm{~km}, 25 \mathrm{~km}, 10 \mathrm{~km}$, and 5 $\mathrm{km}$, respectively. The regional stage analysis produced potential sites. It becames a reference for the screening stage, which was performed in the near area to generate several selected sites. The comparison stage of ranking within a $5 \mathrm{~km}$ radius is to get one selected candidate site. Meanwhile, the final stage is the site evaluation process carried out within a radius of $1 \mathrm{~km}$ to determine design parameters and site characteristics.

Studies on environmental radiology need to be designated around the prospective site as a radiological surveillance zone (RSZ) in terms of emergencies [5]. Figure 1 shows a circle with radius, with sectors centered on the site and the cardinal directions [6]. The radius and sector are adapted to the situation and site conditions. For example, in Onagawa (Japan), the observation radius were made at distances of $1 \mathrm{~km}, 2 \mathrm{~km}, 3 \mathrm{~km}, 4 \mathrm{~km}, 5 \mathrm{~km}, 6 \mathrm{~km}, 7 \mathrm{~km}$, and $8 \mathrm{~km}$ from the reactor [6]. Meanwhile, at the G.A. Siwabessy, Serpong, Banten, the radius were $2 \mathrm{~km}, 4 \mathrm{~km}, 6 \mathrm{~km}, 8 \mathrm{~km}$, and 10 $\mathrm{km}[3]$. Observation points are determined by examining the dominant wind direction and speed in the prospective site and its surroundings.

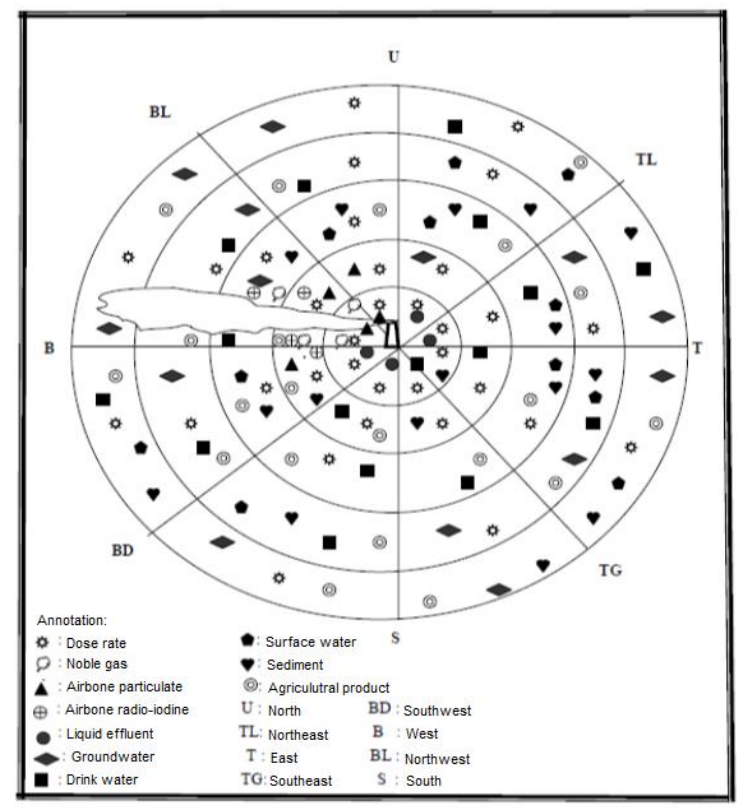

Figure 1. Finger making and observation sectors in eight cardinal directions [6].

For NPP in coastal areas, the distribution of radioactive released to the environment is influenced by sea and land breezes, as shown in Figure 2 [6]. The wind blow direction during the day and at night is known as sea and land breezes. The sea breeze moves in the lower air layer and reaches several kilometers from the coastline, while the land breeze blows above a certain height and meets the flow of the sea breeze below. This situation creates an inversion layer that reduces dispersion, thereby increasing the level of radioactive pollutants around the chimney. The pollutant accumulation occur at the meeting point of the opposite airflow, around A. Hence the chimney height needs to higher than the inversion layer. Therefore, for these reasons, it is important to research prospective site locations to observe wind conditions continuously and determine the height of the inversion layer.

Radionuclides released during normal and abnormal conditions reaches the population through various routes, thereby providing radiation doses to the surrounding environment. The human body contacts this toxic substance through inhalationingestion, and immersion. The atmosphere is the main route that needs to be considered when 
determining the environmental impact of the release of radioactivity into the environment. Further, research needs to be conducted to determine the concentration of radionuclides released into the air, as well as those contaminating the soil through the dispersion and deposition processes. The various paths taken by radionuclides to reach humans by air are shown in Figure 3 [7].

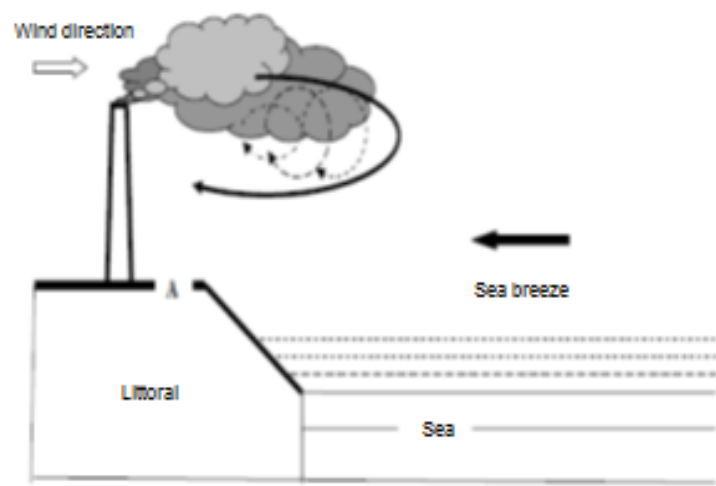

Figure 2. Illustration of wind direction in the coastal area of the prospective NPP site [6].

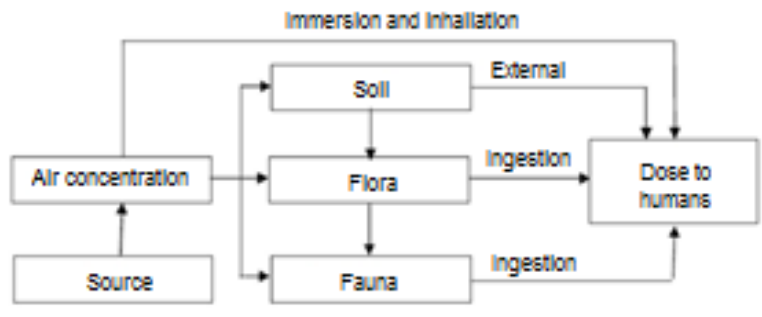

Figure 3. Illustration of the path of a radionuclides source to humans by air [7].

The hydrosphere is an important pathway for the release of radioactive materials to the environment and humans. This pathway includes surface and subsurface water. Surface water includes an open water body at ground level, such as seawater. Although water body meets groundwater, in this case, it is necessary to distinguish them for dispersion and dose studies because these radionuclides usually move quickly on the ground surface. The surface water path for dose studies from source to human is shown in Figure 4 [7].

The release of radioactive material into the water body is a routine, planned, or accidental process. The routine and planned release in the short term must always be within limits permitted by regulations. Therefore, to estimate the dose of this scenario, a surface hydrological study in the site area needs to be conducted. This research determines dilution and dispersion by water body, uptake of radioactivity by sediments and biota, radionuclide transfer mechanisms, identification of exposure pathways to humans via the hydrosphere, and indications of radionuclide exposure pathways [8]. These data are used to evaluate the impact of surface water contamination on the population with appropriate hydrological and radiological modeling. A program of meteorological measurements needs to be initiated and carried out at the prospective site at least 3 years prior to commissioning.

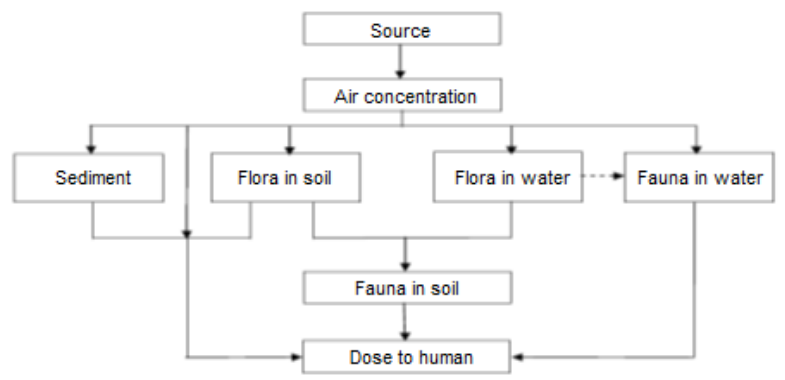

Figure 4. Illustration of the path of a radioactive source to humans through surface water [7].

This radiation study aims to determine individual and population doses. Furthermore, the radiological consequences of having a nuclear facility on the population and the environment need to be as low as reasonably achievable (ALARA) in order to take into account, the social and economic factors. Annual release limits for all facilities within a given site need to be taken simultaneously to ensure that the effective dose limit for anyone outside the site during normal and abnormal operation is less than $1 \mathrm{mSv} / \mathrm{year}$, excluding the contribution of the background radiation dose.

\section{QUALITY ASSURANCE}

Environmental radiology monitoring program needs to provide relevant information regarding radioactivity levels in the biosphere compartment according to applicable regulatory limits. Therefore, environmental radiological monitoring data are compared against standards to decide its potential risks to humans and the environment. Furthermore, a comprehensive quality assurance program needs to be established to control the 
effectiveness of the radiological monitoring and engineering activities during the various stages of the nuclear installation site evaluation [9]. Finally, the monitoring results need to be compiled in a single report by documenting all fieldwork, laboratory tests and analyses, and geotechnical evaluations.

Complete requirements have been described to obtain quality assurance in carrying out measurements in the ISO/IEC 17025 (General requirements for the competence of testing and calibration laboratories). These include requirements of general structure, resources, processes, and management [10]. To ensure the validity of the measurement results, monitoring procedures need to be established and applied consistently. These include the use of reference materials, calibrated tools, work standards, a functional inspection of measuring instruments, retesting of samples, review of measurement results, and intra laboratory comparisons. Measurement data are recorded hence trends are detected with the application of statistical techniques. In situations not compatible with the measurement system, corrective actions are proposed and implemented. Furthermore, the effect on the measurement system is discussed.

\section{DISCUSSION}

The selection of the NPP site requires several procedures, including geotechnical investigations, meteorological data collection and analysis (including sea wave heights, storm cycles, wind direction and speed, and other activities around the coast), seismic (seismic), geological (drilling), hydrological (estimation of flood occurrence and groundwater content), hydrogeological, epidemiological, and environmental radiology studies [11].

Indonesian Government Regulation Number 33 of 2007 article 27 paragraph (1) states that environmental radioactivity monitoring needs to be carried out continuously, periodically, or at any time[12]. Therefore, in this study, radioactivity was carried out in BATAN through (1) continuous monitoring, (2) regular monitoring every 1 and 3 months, and (3) special or non-routine monitoring, as shown in Tables 1 and 2 [3].
Table 1. Examples of environmental components and parameters monitored from nuclear installation activities [3].

\begin{tabular}{|c|c|c|c|}
\hline $\begin{array}{c}\text { Environ } \\
\text { mental } \\
\text { compon } \\
\text { ents } \\
\end{array}$ & $\begin{array}{l}\text { Monitored } \\
\text { parameters }\end{array}$ & $\begin{array}{c}\text { Impact } \\
\text { indicators }\end{array}$ & $\begin{array}{l}\text { Monitoring } \\
\text { frequency }\end{array}$ \\
\hline Air & $\begin{array}{l}\text { - instantaneou } \\
\text { s dose rate } \\
\text { - cumulative } \\
\text { dose } \\
\text { - radioactivity }\end{array}$ & $\begin{array}{l}\text { - exposure } \\
\text { level } \\
\text { - dose rate } \\
\text { - gross } \\
\text { activity }\end{array}$ & $\begin{array}{l}3 \text { months } \\
3 \text { months } \\
3 \text { months/ } \\
\text { continuous }\end{array}$ \\
\hline $\begin{array}{l}\text { Wet } \\
\text { drop }\end{array}$ & $\begin{array}{l}\text { radioactivity in } \\
\text { rainwater }\end{array}$ & $\begin{array}{l}\text { radionuclide } \\
\text { activity in } \\
\text { rainwater }\end{array}$ & 3 months \\
\hline Soil & $\begin{array}{l}\text { radioactivity in } \\
\text { the soil surface }\end{array}$ & $\begin{array}{l}\text { radionuclide } \\
\text { activity in } \\
\text { the soil } \\
\text { surface }\end{array}$ & 3 months \\
\hline Water & $\begin{array}{l}\text { radioactivity in: } \\
\text { - Surface water } \\
\text { - well water }\end{array}$ & $\begin{array}{l}\text { radionuclide } \\
\text { activity in } \\
\text { surface and } \\
\text { well water }\end{array}$ & $\begin{array}{l}3 \text { months } \\
3 \text { months }\end{array}$ \\
\hline $\begin{array}{l}\text { PAM } \\
\text { water }\end{array}$ & $\begin{array}{l}\text { radioactivity in } \\
\text { drinking water }\end{array}$ & $\begin{array}{l}\text { radionuclide } \\
\text { activity in } \\
\text { drinking } \\
\text { water }\end{array}$ & 3 months \\
\hline $\begin{array}{l}\text { Nearest } \\
\text { river } \\
\text { water }\end{array}$ & $\begin{array}{l}\text { radioactivity in: } \\
\text { - Surface water } \\
\text { - sediment }\end{array}$ & $\begin{array}{l}\text { radionuclide } \\
\text { activity in } \\
\text { surface } \\
\text { water and } \\
\text { sediments }\end{array}$ & $\begin{array}{l}3 \text { months } \\
3 \text { months }\end{array}$ \\
\hline Plant & $\begin{array}{l}\text { radioactivity in } \\
\text { grass/plants }\end{array}$ & $\begin{array}{l}\text { radionuclide } \\
\text { activity in } \\
\text { grass/plants }\end{array}$ & 3 months \\
\hline $\begin{array}{l}\text { Wet } \\
\text { drop }\end{array}$ & $\begin{array}{l}\text { radioactivity in } \\
\text { rainwater }\end{array}$ & $\begin{array}{l}\text { radionuclide } \\
\text { activity in } \\
\text { rainwater }\end{array}$ & 3 months \\
\hline Soil & $\begin{array}{l}\text { radioactivity in } \\
\text { the soil surface }\end{array}$ & $\begin{array}{l}\text { radionuclide } \\
\text { activity in } \\
\text { the soil } \\
\text { surface }\end{array}$ & 3 months \\
\hline
\end{tabular}

BAPETEN sets the standard for the level of radioactivity in the environment, which is the highest limit value expressed in the concentration of radionuclide activity in the environment [13]. Examples of standard values for radioactivity levels in the air and water body for some primordial natural radionuclides are shown in Table 3. An environmental gamma radiation is the measuring instrument used to determine the concentration levels of natural radionuclides (U-238, U-235, Th-232, and Ra-226) in rocks.

Environmental radiological measurements were carried out at levels where the detected radionuclides are indistinguishable from natural background-radiation levels, thereby increasing their relative uncertainty. This process also raises debate and doubts on 
the measurement results due to the difficulty in establishing a minimum detection level.

Table 2. Examples of environmental parameters monitored under normal release conditions [3].

\begin{tabular}{|c|c|c|}
\hline $\begin{array}{l}\text { Release } \\
\text { type }\end{array}$ & Monitored parameters & $\begin{array}{l}\text { Monitoring } \\
\text { frequency }\end{array}$ \\
\hline \multirow[t]{4}{*}{ Airborne } & $\begin{array}{l}\text { External dose: } \\
\text { - gamma dose rate } \\
\text { - cumulative gamma } \\
\text { dose }\end{array}$ & $\begin{array}{l}\text { - } \text { continuous and } \\
\text { momentary } \\
\text { - } 3 \text { months } \\
\text { measurement }\end{array}$ \\
\hline & $\begin{array}{l}\text { Air deposition: } \\
\text { - air } \\
\text { - rainwater } \\
\text { - surface ground }\end{array}$ & $\begin{array}{l}\text { - taking and } \\
\text { measuring } \\
\text { samples } 1 \text { and } 3 \\
\text { months, } \\
\text { - continuous } \\
\text { collection and } \\
\text { measurement } 3 \\
\text { months }\end{array}$ \\
\hline & $\begin{array}{l}\text { Food material: } \\
\text { - vegetables } \\
\text { - drinking } \\
\text { water/groundwater }\end{array}$ & $\begin{array}{l}3 \text { months sampling } \\
\text { and measurement }\end{array}$ \\
\hline & $\begin{array}{l}\text { Land/grass/wild plant } \\
\text { indicators }\end{array}$ & $\begin{array}{l}3 \text { months sampling } \\
\text { and measurement }\end{array}$ \\
\hline \multirow[t]{2}{*}{ Fluid } & $\begin{array}{l}\text { Water distribution: } \\
\text { - Surface water } \\
\text { - sediment }\end{array}$ & $\begin{array}{l}3 \text { months sampling } \\
\text { and measurement }\end{array}$ \\
\hline & $\begin{array}{l}\text { Aquatic food } \\
\text { ingredients: } \\
\text { - freshwater fish }\end{array}$ & $\begin{array}{l}3 \text { months sampling } \\
\text { and measurement }\end{array}$ \\
\hline
\end{tabular}

Table 3. Standard levels of radioactivity in the air and water $[13,14]$

\begin{tabular}{ccccc}
\hline No & $\begin{array}{c}\text { Nucli } \\
\text { des }\end{array}$ & $\begin{array}{c}\text { Standard } \\
\text { Level of } \\
\text { Radioactivi } \\
\text { ty in Air } \\
\left(\mathrm{Bq} / \mathrm{m}^{3}\right)^{[13]}\end{array}$ & $\begin{array}{c}\text { Derived Air } \\
\text { Concentratio } \\
\mathbf{n}(\mathrm{DAC}) \\
\left(\mathrm{Bq} / \mathbf{m}^{3}\right)^{[14]}\end{array}$ & $\begin{array}{c}\text { Radioactivi } \\
\text { ty Level } \\
\text { Standards } \\
\text { in Water } \\
\text { Body } \\
\left(\mathrm{Bq} / \mathbf{m}^{3}\right)^{[13]}\end{array}$ \\
\hline 1 & $\mathrm{Ra}-$ & $1,8 \times 10^{-3}$ & 0,32 & $1,0 \times 10^{3}$ \\
& 226 & & & \\
2 & $\mathrm{Th}-$ & $2,3 \times 10^{-3}$ & 0,0059 & $7,1 \times 10^{2}$ \\
3 & 232 & & & \\
4 & $\mathrm{U}-235$ & $1,5 \times 10^{-2}$ & 0,26 & $1,9 \times 10^{4}$ \\
\hline
\end{tabular}

Dosimetry service laboratories are mandated to perform the following tasks (1) determine and record the lowest measurable concentration or exposure in air at a $95 \%$ confidence level with an overall accuracy of $\pm 50 \%$ or less, (2) state the lowest measurable exposure in the same units, and (3) calculate the limits where the correct count is within $95 \%$, as shown in the following equation [15].

$$
\begin{aligned}
& L L=\left(C_{t}-C_{b}\right)-1.96 \sqrt{ }\left(C_{t}+C_{b}\right) \\
& U L=\left(C_{t}-C_{b}\right)+1.96 \sqrt{ }\left(C_{t}+C_{b}\right)
\end{aligned}
$$

Where $L L$ denotes the lower limit, $U L$ is the upper limit, $C_{t}$ is the total count, $C_{b}$ is the background count for a certain time, and $C_{t}-C_{b}$ is the net count (net).

An example of the application is shown in Table 3, where the derived air concentration (DAC) for the nuclide U-238 is $0.27 \mathrm{~Bq} / \mathrm{m}^{3}$. This was achieved using a suction pump fitted with a pollutant capture at a sampling rate of $2.5 \mathrm{~L} / \mathrm{min}\left(0.0025 \mathrm{~m}^{3} / \mathrm{min}\right)$ for 6 hours. The filter was chopped with a detector at an efficiency of $0.43 \mathrm{cps} / \mathrm{Bq}$ and background count $\left(C_{b}\right)$ of $1 \mathrm{cpm}$. To meet the standard value of derived air concentration, the activity of nuclides were collected in the filter with values of $0.27 \mathrm{~Bq} / \mathrm{m}^{3} \times 0.0025 \mathrm{~m}^{3} / \min \times 60$ $\mathrm{min} /$ hour $\mathrm{x} 6$ hours $=0.243 \mathrm{~Bq}$. Total count of detector $=1 \mathrm{cpm}+(0,243 \mathrm{~Bq} \times 0,43 \mathrm{cps} / \mathrm{Bq} \times$ $60 \mathrm{~s} / \mathrm{min})=7.27 \mathrm{cpm}$. Supposing the background and sample were chopped for 20 minutes, then $C_{t}=145, C_{b}=20$ and $\left(C_{t}-C_{b}\right)=$ 125. Using equations (1) and $2, L L=101$ and $U L=148$, with the best correct count $\left(C_{t}-C_{b}\right)$ $=125$.

Table 4 shows that the periodic and consistent internal quality control is needed to obtain quality measurement. The main objectives of internal quality control are to (1) ensure that calibration is maintained, (2) monitor equipment drift, and (3) check the consistency of results [16]. Quality control samples represent stable and original samples. Furthermore, dosimetry service laboratories need to participate in inter-laboratory comparative trials to evaluate the performance of the quality system.

Table 4. Types of sample quality control and their internal quality assurance [16]

\begin{tabular}{lccc}
\hline Type of Sample & Precision & $\begin{array}{c}\text { Accuracy } \\
\text { monitoring }\end{array}$ & Accuracy \\
\hline $\begin{array}{l}\text { Standard } \\
\text { solution }\end{array}$ & Yes & No & No \\
Blank sample & Yes & Yes & No \\
Nature sample & Yes & No & No \\
Nature+sharp & No & Yes & No \\
Sample & & & \\
Mock sample & Yes & Yes & Yes \\
Reference & Yes & Yes & Yes \\
material & & & \\
\hline
\end{tabular}

The measurement process in the laboratory need to be guaranteed through competent personnel, scheduled sampling, an established system of quality control and assurance, use of written and legal analytical procedures, use of standard and calibrated measuring instruments, quality control of 
samples and equipment, participation in comparative tests, and internal and external audits [17,18]. Sample quality is controlled using blind, blank, spiked, and duplicate samples. Equipment quality control includes background and works standard material measurements, periodic calibration, and control tests.

The aspects of a quality assurance program that need to be created and implemented are as follows, (1) organizational structure related to the management and implementation of monitoring programs, such as quality assurance policies. (2) qualifications of personnel to carry out monitoring functions, (3) written procedures for all data-generating activities, such as dose calculation and measurement, sample collection, management, transfer, preparation and analysis. This is in addition to data recording and selection, review and reporting, and disposal of residual samples. (4) maintenance of accurate recording systems and non-multi-interpretation. These aspects also consist of (5) environmental sampling quality control, (6) radio-analytic laboratory quality control, (7) radioactive liquid monitoring system quality control, (8) verification and validation of all aspects and activities, (9) assessment, audit and surveillance to evaluate the effectiveness of activities and monitor, as well as control the monitoring program in a systematic and independent manner, and (10) preventive and corrective action.

In line with the above, the quality assurance program is always applied in a real, consistent and traceable manner in every stage of the activity. Furthermore, actions to ensure implementation are carried out throughout the stages of the activity, starting from input and output sources. The potential risks of each activity such as planning, implementation, measurement, and improvement stages, are always identified, anticipated, controlled, and evaluated [19].

\section{CONCLUSION}

In conclusion, the reliability of environmental radiology monitoring and assurance for site selection is determined by the laboratory's ability to produce analytical data and provide quality results. Therefore, determining parameters process related to radiological measurements involves technical analysis and assessment, which requires extensive knowledge and experience. Previous data associated with this research need to be stored in an easily retrievable form. Furthermore, these results need to be properly documented with sufficient detail on the strategies needed to review and assess potential risks verifiable by an independent group.

\section{ACKNOWLEDGMENTS}

The authors are grateful to PKSEN BATAN for providing facilities for Seminar presentations, SENTEN 2020.

\section{REFERENCES}

1. Government of Indonesia, "Regulation of the Government of the Republic of Indonesia Number 2 of 2014 concerning Licensing of Nuclear Installations and Utilization of Nuclear Materials", Ministry of State Secretariat of the Republic of Indonesia (2014).

2. Nuclear Energy Supervisory Agency (BAPETEN), "BAPETEN Regulation Number 4 of 2018 concerning Safety Provisions for Evaluation of Nuclear Installation Sites", BAPETEN (2018).

3. National Nuclear Energy Agency (BATAN), "Standard Batan SB 016 BATAN:2014 Radiation Protection and Safety BATAN, Batan (2014).

4. IAEA, "Site Evaluation for Nuclear Installations", International Atomic Energy Agency (IAEA) Safety Standards Series, Safety Requirements No. NS-R-3 (Rev.1), Vienna (2016).

5. Government of India, "Site Evaluation of Nuclear Facilities", Atomic Energy Regulatory Board (AERB) Safety Code No. AERB/NF/SC/S (Rev.1), Mumbai (2014).

6. Sutarman, "Pemantauan Lingkungan Pada Kegiatan Pembangkit Listrik Tenaga Nuklir", Buletin Alara Volume 8 Number 1, Jakarta (2006).

7. Roshan A.D., Shylamoni P., and Sourav Acharya, "Monograph on Siting of Nuclear Power Plants", Atomic Energy Regulatory Board (AERB), Mumbai, India. https://www.aerb.gov.in/storage/uploads/M 
onographs/monographs9r5vM.pdf

(accessed on May 2020)

8. AERB, "Hydrological Dispersion of Radioactive Materials in Relations to Nuclear Power Siting”, Atomic Energy Regulatory Board (AERB) Safety Guide NO. AERB/SG/S-1, Mumbai, India (1998)

9. U.S. Nuclear Regulatory Commission, "Quality Assurance for Radiological Monitoring Programs - Effluent Streams and the Environment", Office of Nuclear Regulatory Research, Regulatory Guide 4.15 Revision 2, USA(2007).

10. ISO/IEC, "General Requirements for the Competence of Testing and Calibration Laboratories", International Standards ISO/IEC 17025:2017(E) Third Edition, Switzerland (2017).

11. AERB, "Quality Assurance in Siting of Nuclear Power Plants", Atomic Energy Regulatory Board (AERB) Safety Guide No. AERB/NPP/SG/S-10, Mumbai (2005).

12. Government of Indonesia, "Government Regulation of the Republic of Indonesia Number 33 of 2007 concerning Safety of Ionizing Radiation and Safety of Radioactive Sources", Ministry of State Secretariat of the Republic of Indonesia (2007).

13. Nuclear Energy Supervisory Agency (BAPETEN), "BAPETEN Regulation Number 7 of 2017 concerning Environmental Radioactivity Limit Values", BAPETEN (2017).
14. US DOE, "Derived Concentration Technical Standard", U.S Department of Energy (DOE) Standard DOE-STD-11962011, Washington (2011).

15. CNSC, "Technical and Quality Assurance Requirements for Dosimetry Services", Canadian Nuclear Safety Commission (CNSC) Regulatory Standard S-106 revision 1, Ontario, Canada (2006).

16. Maria Betti and Laura Aldeve de las Heras, "Quality Assurance for the Measurements and Monitoring of Radioactivity in the Environment", Journal of Environmental Radioactivity 72 (2004).

17. EC, "Environmental Radiological Monitoring in the Slovak Republic Monitoring of Liquid and Gaseous Discharges at the Mochovce NPP", European Commission (EC) Technical Report of the Verification under the Termas of Article 35 of the European Treaty, Bratislava (2014).

18. EC, "Discharge and Environmental Monitoring and National Environmental Radioactivity Monitoring Network in the Vicinity - Almaraz Nuclear Power Plant", European Commission (EC) Technical Report of the Verification under the Termas of Article 35 of the European Treaty, Almaraz, Spain (2018).

19. NATIONAL NUCLEAR ENERGY AGENCY, "BATAN Management System Manual" Number MSMB/KN 09 06/SMN 3, BATAN (2018) 
Jurnal Forum Nuklir Volume 14, Nomor 2, November 2020 